\title{
PENGARUH KONSENTRASI STARTER Streptococcus thermophillus DAN LAMA FERMENTASI TERHADAP KARAKTERISTIK MINUMAN LAKTAT DARI BENGKUANG (Pachyrrhizus erosus)
}

\author{
THE INFLUENCE OF STARTER CONCENTRATION Streptococcus thermopillus AND \\ TIME OF FERMENTATION AGAINST CHARACTERISTIC OF \\ LACTIC DRINK FROM BENGKOANG (Pachyrrhizus erosus)
}

\author{
Suharyono AS ${ }^{1)}$, Muhamad Kurniadi') \\ 1) Dosen Jurusan Teknologi Hasil Pertanian Fakultas Pertanian Universitas Lampung, Jl.Ir.Sumantri \\ Brojonegoro No.1 Bandar Lampung 35145 \\ 2) Peneliti UPT.Balai Pengembangan Proses dan Teknologi LIPI, Desa Gading, Playen Gunungkidul, \\ Yogyakarta, Tlp.0274392570, email:HM_KUR@yahoo.com
}

\begin{abstract}
Lactic drink is fermentation drink which is made by using bacteria starter lactic acid. Important factor which influence the success of making lactic drink is concentration of starter and time of fermentation. The main problem which is faced is it is not known yet about the correct starter concentration and time of fermentation to produce lactic drink from bengkoang which suitabel with lactic drink standard product and with the best characteristic.

The objectives of this research were to get starter concentration and time of fermentation which could produced lactic drink from bengkoang that suitabel with lactic drink standard product and with the best characteristic. Treatments of this research consisted of two factors and three repetitions. The main factor was starter concentration and second factor was time of fermentation on the process of making lactic drink from bengkoang. Treatments for starter concentration (S) consisted of three stages. They were $5 \%, 10 \%, 15 \%(v / v)$, and time of fermentation $(F)$ consisted of three stages, they were 18 hours, 20 hours and 22 hours. One unit experiment used work volume of $150 \mathrm{ml}$. Data from observation result was analyzed descriptively and presented in form tabel and graph.

The result of this research showed that increasing of starter concentration and time of fermentation gave positive influence towards increasing of total lactic acid, decreasing $\mathrm{pH}$, total increasing of lactic acid bacteria, and accepting of taste. The result showed that the best treatment was achieved at treatment with starter concentration $10 \%$ and time of fermentation 22 hours with total lactic acid 1,95\%, pH 3,8, total lactic acid bacteria 9,67 log colony/ml, and has taste score 3,00 (quite delight).
\end{abstract}

Keywords : bengkoang, lactate drink, starter, Streptococcus thermopillus

\begin{abstract}
ABSTRAK
Minuman laktat adalah minuman fermentasi yang dibuat dengan menggunakan starter bakteri asam laktat. Faktor penting yang mempengaruhi keberhasilan dalam pembuatan minuman laktat ini adalah konsentrasi starter dan waktu fermentasi. Masalah utama yang dihadapi adalah belum diketahui konsentrasi stater yang tepat dan waktu fermentasi untuk menghasilkan minuman laktat dari bengkoang yang sesuai dengan standar produk minuman laktat dan dengan karakteristik terbaik.

Penelitian ini bertujuan untuk memperoleh konsentrasi starter dan waktu fermentasi yang dapat menghasilkan minuman laktat yang sesuai dengan standar produk minuman laktat dan dengan karakteristik terbaik. Percobaan dalam penelitian ini terdiri atas dua faktor dan tiga kali ulangan. Faktor utama yang digunakan adalah konsentrasi starter dan faktor kedua adalah waktu fermentasi pada proses pembuatan minuman laktat dari bengkoang. Perlakuan konsentrasi starter (S) terdiri atas tga tahap yaitu 5\%, 10\% dan 15\% (v/v) dan waktu fermentasi (F) yang terdiri atas tiga tahap yaitu 18 jam, 20 jam dan 22 jam. Satu eksperimen menggunakan volume $150 \mathrm{ml}$. Data hasil penelitian dianalisis secara deskriptif dan ditampilkan dalam bentuk tabel dan grafik. Hasil penelitian ini adalah peningkatan konsentrasi starter dan waktu fermentasi memberikan pengaruh terhadap peningkatan total bakteri asam laktat dan penerimaan rasa. Hasil penelitian menunjukkan bahwa perlakuan terbaik dicapai pada perlakuan dengan konsentrasi starter $10 \%$ dan waktu fermentasi 22 jam dengan total asam laktat 1,95\%, pH 3,8, total bakteri asam laktat 9,67 log koloni/ml dan memiliki skor rasa 3,00 (agak suka).
\end{abstract}

Kata kunci : bengkoang, minuman laktat, starter, Streptococcus thermophillus

Jurnal Teknologi Hasil Pertanian, Vol. I, No 1 Februari 2010 


\section{PENDAHULUAN}

Tanaman bengkuang (Pachyrrhizus erosus) atau bengkoang sudah sangat dikenal baik oleh masyarakat Indonesia. Umbi tanaman bengkuang biasa dimanfaatkan sebagai buah atau bagian dari beberapa jenis masakan. Bengkuang memiliki kandungan kalori rendah; kurang dari $10 \%$ karbohidrat, dan $1,4 \%$ protein berdasarkan bobot segar (Yamaguchi dan Rubatzky, 1998). Umbi bisa dimakan segar, dibuat rujak, atau asinan. Bengkuang juga ternyata memiliki khasiat sebagai obat yang bermanfaat bagi kesehatan. Kandungan kimia bengkuang diantaranya adalah pachyrhizon, rotenone, vitamin B1, vitamin C, air dan lain-lain (Anonim, 2007a). Umbinya mengandung gula, zat besi, pati, fosfor dan kalsium (Wirakusumah, 2007). Selain itu, Umbi bengkuang juga memiliki efek pendingin karena mengandung kadar air $86-90 \%$. Rasa manis bengkuang berasal dari suatu oligosakarida yang disebut inulin (Anonim, 2008 ${ }^{\mathrm{a}}$ ).

Bengkuang merupakan salah satu komoditas hortikultura yang banyak diminati oleh masyarakat sebagai bahan konsumsi. Bengkuang juga telah dimanfaatkan sebagai bahan baku pembuatan produk-produk kecantikan seperti lulur bengkuang, handbody bengkuang, dan sebagainya. Namun demikian, produktivitas tanaman bengkuang yang cukup tinggi menyebabkan bengkuang masih belum dapat dimanfaatkan secara optimal sehingga bengkuang bukanlah buah yang memiliki nilai ekonomis tinggi dan berharga mahal. Menurut Yamaguchi dan Rubatzky (1998), hasil panen umbi bengkuang berkisar antara 4 ton hingga 45 ton/ha, tergantung pada kondisi pertumbuhan. Bahkan dalam kondisi yang baik hasil panen umbi bengkuang dipastikan dapat mencapai 30 ton/ha (Williams, dkk., 1993). Berdasarkan hasil survei di daerah pasar Bandar Jaya Lampung Tengah, pasokan bengkuang di pasar Bandar Jaya perhari mencapai $240-300 \mathrm{Kg}$.

Pengolahan merupakan salah satu cara yang dapat dilakukan untuk memanfaatkan bengkuang secara optimal.
Melalui proses pengolahan menjadi suatu produk, maka daya simpan bengkuang menjadi lebih lama dan jangkauan pasar akan lebih luas. Hal ini juga dapat lebih meningkatkan nilai ekonomis bengkuang. Selain itu, proses pengolahan bengkuang akan menambah keragaman jenis makanan dan minuman. Salah satu bentuk produk olahan yang dapat dibuat dari bengkuang adalah minuman laktat.

Minuman laktat adalah minuman asam terfermentasi yang dibuat dengan menggunakan starter bakteri asam laktat. Minuman laktat yang sudah sangat dikenal di masyarakat adalah yakult ataupun yoghurt. Yakult adalah bahan pangan hasil fermentasi susu oleh bakteri asam laktat (Lactobacillus casei) yang mempunyai flavor khas dan dengan rasa asam yang segar. Minuman laktat yang dibuat dengan menggunakan starter tunggal misalnya minuman laktat dari sari kulit nanas (Oktarini, 2006), minuman kesehatan dari sari buah sirsak yang difermentasi dengan Lactobacillus casei (Marniza, 2006). Bengkuang merupakan salah satu komoditi yang belum pernah dicoba untuk dibuat menjadi minuman laktat, sehingga peneliti ingin mencoba untuk mengolah bengkuang menjadi minuman laktat dari bengkuang.

Faktor penting yang mempengaruhi keberhasilan pada proses pembuatan minuman laktat adalah konsentrasi starter dan lama fermentasi. Konsentrasi starter dan lama fermentasi dapat mempengaruhi karakteristik minuman laktat yang dihasilkan. Dalam hal ini, masalah utama yang dihadapi adalah belum diketahui konsentrasi starter dan lama fermentasi yang tepat untuk menghasilkan minuman laktat dari bengkuang yang sesuai dengan standar produk minuman laktat dan dengan karakteristik yang terbaik.

Penelitian ini bertujuan untuk mendapatkan konsentrasi starter dan lama fermentasi yang menghasilkan minuman laktat dari bengkuang yang sesuai dengan standar produk minuman laktat dan dengan karakteristik yang terbaik. 


\section{METODE PENELITIAN}

\section{Bahan dan Alat}

Bahan utama yang digunakan dalam pembuatan minuman probiotik ini, yaitu buah bengkuang (Pachyrrhizus erosus) yang diperoleh dari Bandar Jaya Lampung Tengah dan starter bakteri Streptococcus thermophilus yang diperoleh dari Pusat Antar Universitas Pangan dan Gizi, UGM Yogyakarta. Bahan tambahan yang digunakan adalah glukosa, susu skim, dan sukrosa. Bahan untuk analisa antara lain aquadest, media MRS Broth (De Mann Ragoso Sharp) dan MRS Agar untuk pertumbuhan kultur, larutan $\mathrm{NaOH} 0,1 \mathrm{~N}$, Indikator $\mathrm{pp}$, alkohol, dan $\mathrm{NaCl}$. Alat-alat yang digunakan antara lain timbangan, blender, baskom, plastik, kain saring, wadah botol, colony counter (Stuart Scientific), inkubator (Memmert 50Hz), pH meter (HI 8424), autoklaf (Witeclave Daihan Scienific 1 atm.), spatula, pisau stainless steel, alumunium foil, kapas, tabung reaksi, cawan petri, erlenmeyer, mikropipet, gelas ukur, bunsen.

\section{Metode Penelitian}

Perlakuan dalam penelitian ini terdiri dari dua faktor dan tiga ulangan. Faktor pertama yang digunakan adalah konsentrasi starter dan faktor kedua adalah taraf lama fermentasi pada proses pembuatan minuman probiotik dari bengkuang. Perlakuan konsentrasi starter terdiri dari tiga taraf, yaitu $5 \%, 10 \%$, dan $15 \% \quad(\mathrm{v} / \mathrm{v})$, dan perlakuan lama fermentasi terdiri dari tiga taraf, yaitu 18 jam, 20 jam, dan 22 jam. Satu unit percobaan menggunakan volume kerja yaitu sebanyak $150 \mathrm{ml}$. Data dari hasil pengamatan dianalisis secara deskriptif dan disajikan dalam bentuk tabel dan grafik.

\section{HASIL DAN PEMBAHASAN}

\section{Total Bakteri Asam Laktat}

Dari data hasil penghitungan total bakteri asam laktat pada minuman laktat dari bengkung didapat nilai Log bakteri asam laktat berkisar antara 8,73-9,71 koloni/ml. Nilai rata-rata tertinggi $9,71 \log$ koloni/ml diperoleh dari perlakuan konsentrasi starter
$15 \%$ dan lama fermentasi 22 jam. Sedangkan nilai rata-rata terendah $8,73 \mathrm{log}$ koloni/ml diperoleh dari perlakuan konsentrasi starter 5\% dan lama fermentasi 18 jam.

Mengacu pada standar untuk minuman laktat, maka produk minimal harus mengandung bakteri asam laktat sebesar 1,0 x $10^{7} \mathrm{koloni} / \mathrm{ml}$ (Orihara et al., 1992 dalam Sihaloho, 2008). Sriwidowoti (2003) menyebutkan bahwa jumlah mikroba dalam produk laktat agar dapat memberikan manfaat kesehatan adalah berjumlah $10^{7}$. $10^{10} \mathrm{koloni} / \mathrm{ml}$ sehingga dapat bersaing dengan mikroba patogen. Berdasarkan data tersebut, maka dapat dikatakan bahwa minuman laktat dari bengkuang hasil penelitian ini telah memenuhi standar minuman laktat.

Berdasarkan hasil pengujian total bakteri asam laktat dapat diketahui bahwa penambahan konsentrasi starter dan lama fermentasi berpengaruh terhadap total bakteri asam laktat pada minuman laktat dari bengkuang ini. Hal ini terlihat bahwa pada penambahan konsentrasi starter dan dengan semakin lamanya waktu fermentasi maka dapat meningkatkan total bakteri asam laktat produk minuman laktat tersebut. Hal ini sesuai dengan penelitian Afrizal (1989), bahwa semakin tinggi tingkat konsentrasi penambahan starter yang ditambahkan, maka akan meningkatkan total bakteri asam laktat yang dihasilkan. Selain itu juga, diduga bahwa pada lama fermentasi 22 jam waktu tersebut dapat dimanfaatkan secara optimal oleh bakteri asam laktat untuk pertumbuhannya dengan mendapatkan suplai energi dari hasil perombakan karbohidrat, glukosa, dan laktosa dalam susu skim.

\section{Total Asam Laktat}

Total asam dinyatakan sebagai total asam laktat karena bakteri Streptococcus thermophillus yang digunakan sebagai starter merupakan golongan bakteri asam laktat homofermentatif yang menghasilkan asam laktat sebagai komponen utamanya. Total asam laktat yang diperoleh pada minuman laktat dari bengkuang ini berkisar antara $1,74 \%-2,10 \%$. Nilai rata-rata tertinggi 
2,10\% diperoleh dari perlakuan konsentrasi starter $15 \%$ dan lama fermentasi 22 jam, sedangkan nilai rata-rata terendah $1,74 \%$ diperoleh dari perlakuan konsentrasi starter 5\% dan lama fermentasi 18 jam. Konsentrasi asam laktat pada penelitian ini relatif sama dengan produk minuman fermentasi nabati dari penelitian sebelumnya Sihaloho (2008). Mengacu pada standar mutu minuman probiotik pada SNI 01-2981-1992, yaitu kandungan asam laktat berkisar antara 0,5$2,0 \%$. Hal ini menunjukkan bahwa total asam laktat minuman laktat dari bengkuang pada penelitian ini dapat memenuhi standar mutu SNI.

Total asam laktat merupakan pengukuran semua komponen asam, baik yang terdisosiasi maupun yang tidak terdisosiasi, disamping asam laktat terkandung juga asam-asam lain yang mudah terdisosiasi, seperti asam asetat dan asam format (Hernawati, 2002). Berdasarkan hasil pengujian total asam laktat terhadap minuman probiotik dari bengkuang dapat diketahui bahwa penambahan konsentrasi starter dan lama fermentasi berpengaruh terhadap total asam laktat minuman probiotik dari bengkuang. Hal ini terlihat bahwa pada penambahan konsentrasi starter dan semakin lamanya waktu fermentasi ternyata dapat meningkatkan total asam laktat produk minuman laktat tersebut, dengan nilai ratarata tertinggi $2,10 \%$ diperoleh dari perlakuan konsentrasi starter $15 \%$ dan lama fermentasi 22 jam. Pada penambahan konsentrasi starter $15 \%$ memiliki total asam laktat yang cukup tinggi, hal ini diduga karena semakin banyak jumlah starter yang diberikan dalam produk maka akan semakin banyak jumlah bakteri Strepcococus thermophilus yang dapat menghidrolisis karbohidrat menjadi asam laktat. Disamping itu, adanya glukosa dan susu skim juga dapat digunakan oleh bakteri tersebut sebagai sumber energi sehingga pembentukan asam laktat semakin optimal.

Menurut Nining (1982) lama fermentasi berpengaruh terhadap konsentrasi asam laktat yang dihasilkan, yaitu dengan bertambahnya waktu fermentasi maka konsentrasi asam laktat yang terbentuk akan semakin meningkat. Hal ini disebabkan karena semakin lama waktu fermentasi maka waktu terjadinya proses perombakan karbohidrat dan pemanfaatan nutrient oleh bakteri Strepcococus thermophilus akan lebih lama dan optimal sehingga jumlah asam laktat yang dihasilkan akan semakin tinggi. Selain itu, semakin banyak jumlah starter yang diberikan dalam produk maka akan semakin banyak jumlah bakteri Strepcococus thermophilus yang dapat menghidrolisis karbohidrat menjadi asam laktat. Disamping itu, adanya glukosa dan susu skim juga dapat digunakan oleh bakteri tersebut sebagai sumber energi untuk merubah laktosa dalam susu skim menjadi asam laktat. Pada perlakuan konsentrasi starter 5\% dan 10\% peningkatan konsentrasi asam tidak terlalu tinggi namun peningkatan konsentrasi asam cukup tinggi pada perlakuan konsentrasi starter $15 \%$. Hal ini diduga karena penambahan starter masih relatif sedikit. Semakin tinggi konsentrasi starter yang ditambahkan, maka akan semakin tinggi jumlah bakteri Strepcococus thermophilus yang dapat menghidrolisis karbohidrat menjadi asam laktat dan dapat meningkatkan kemampuan bakteri untuk memecah laktosa dalam susu skim. Laktosa akan didegradasi atau dirombak oleh Strepcococus thermophilus menjadi glukosa dan galaktosa yang selanjutnya diubah menjadi asam laktat sebagai produk utama (Helferich dan Weshoff, 1980).

\section{Nilai Keasaman (pH)}

Nilai keasaman $(\mathrm{pH})$ menunjukkan tingkat atau derajat keasaman suatu produk, sehingga semakin rendah nilai $\mathrm{pH}$ maka tingkat keasaman produk minuman fermentasi laktat semakin tinggi. Diketahui bahwa $\mathrm{pH}$ awal sari bengkuang yaitu sekitar 6, namun adanya penambahan starter kemungkinan $\mathrm{pH}$ sari bengkuang akan turun menjadi lebih rendah. Pada proses fermentasi, bakteri Streptococcus thermophilus akan menghasilkan asam-asam organik dan $\mathrm{CO}_{2}$. Asam laktat yang dihasilkan oleh bakteri asam laktat tersebut akan tersekresikan keluar sel dan akan terakumulasi dalam cairan fermentasi. Meningkatnya jumlah asam yang 
disekresikan tersebut, maka keasaman minuman laktat akan meningkat, dan peningkatan akumulasi asam laktat ini akan menyebabkan terjadinya penurunan $\mathrm{pH}$ (Widowati et al., 2003). Berdasarkan penelitian yang telah dilakukan, tingkat keasaman $(\mathrm{pH})$ minuman laktat dari bengkuang ini berkisar antara 3,78 hingga 4,04. Menurut Wood (1982) dalam Kustianigrum (2003) nilai $\mathrm{pH}$ minuman laktat berkisar 3,8-4,6, sehingga dapat dikatakan bahwa nilai $\mathrm{pH}$ minuman laktat dari bengkuang pada penelitian ini dapat memenuhi nilai $\mathrm{pH}$ minuman laktat.

Berdasarkan hasil pengujian nilai $\mathrm{pH}$ minuman laktat dari bengkuang dapat diketahui bahwa pada penambahan konsentrasi starter dan dengan semakin lamanya waktu fermentasi maka dapat menurunkan nilai $\mathrm{pH}$ produk minuman laktat tersebut. Hal ini diduga karena semakin lama waktu fermentasi maka perombakan karbohidrat oleh bakteri asam laktat akan semakin lama dan optimal sehingga dihasilkan asam yang kemudian akan terakumulasi sehingga dapat menurunkan nilai $\mathrm{pH}$. Peningkatan akumulasi asam laktat tersebut akan mempengaruhi $\mathrm{pH}$ lingkungan. Asam laktat yang dihasilkan akan tersekresi keluar sel dan akan terakumulasi dalam cairan fermentasi. Menurut Suryono, dkk.(2005), semakin tinggi jumlah asam laktat dalam lingkungan, maka potensi menurunnya $\mathrm{pH}$ lingkungan juga semakin besar, bahkan dapat memberi rasa yang spesifik pada produk.

Pada penelitian ini, nilai $\mathrm{pH}$ yang didapat berbanding terbalik dengan nilai total asam laktat. Ketika produk memiliki $\mathrm{pH}$ 4, asam laktat mudah mengalami disosiasi sehingga menghasilkan $\mathrm{H}^{+}$dalam jumlah banyak. Adanya ion $\mathrm{H}^{+}$inilah yang sangat mempengaruhi nilai $\mathrm{pH}$. Oleh karena itu, semakin banyak jumlah asam laktat maka semakin besar pula ion $\mathrm{H}^{+}$yang terukur pada $\mathrm{pH}$-meter, sehingga $\mathrm{pH}$ lingkungan semakin rendah. Penurunan $\mathrm{pH}$ pada minuman laktat ini sangat menguntungkan karena dapat menghambat pertumbuhan mikroba berbahaya yang dapat mengkontaminasi produk tersebut (Winarno, 1997).

\section{Tingkat Kekeruhan}

Tingkat kekeruhan ditentukan berdasarkan perbandingan antara volume bagian keruh dengan volume total (Suter, 1981). Nilai tingkat kekeruhan minuman laktat dari bengkuang yang diperoleh pada penelitian ini berkisar antara 20,33\% hingga $32,33 \%$.

Berdasarkan hasil pengujian tingkat kekeruhan terhadap minuman laktat dari bengkuang dapat diketahui bahwa nilai ratarata tertinggi $32,33 \%$ diperoleh dari perlakuan konsentrasi starter $15 \%$ dan lama fermentasi 22 jam, yang berarti bahwa produk minuman laktat tersebut semakin tidak stabil karena semakin banyaknya endapan. Nilai rata-rata terendah $20,33 \%$ diperoleh dari perlakuan konsentrasi starter $5 \%$ dan lama fermentasi 18 jam. Peningkatan total padatan terlarut dari produk tersebut disebabkan oleh penggumpalan protein yang ada pada bengkuang dan kasein pada susu dengan adanya asam laktat yang terbentuk. Penurunan $\mathrm{pH}$ disebabkan karena adanya proses fermentasi terhadap karbohidrat, glukosa dan laktosa oleh bakteri asam laktat yang menghasilkan sebagian besar asam laktat. Tamimme dan Deeth (1980) yang dikutip Setyaningsih (1992) menyatakan bahwa dengan turunnya $\mathrm{pH}$ maka keseimbangan protein dan kasein terganggu dan pada $\mathrm{pH}$ di bawah titik isoelektriknya ( $\mathrm{pH}$ 4,6) akan menggumpal membentuk koagulum sehingga terbentuk struktur semi padat. Oleh sebab itu, hasil yang diperoleh pada penelitian ini semakin banyak konsentrasi starter yang ditambahkan dan semakin lama waku fermentasi maka nilai tingkat kekeruhan produk semakin meningkat, yang berarti bahwa produk minuman laktat tersebut semakin tidak stabil karena semakin banyaknya endapan.

\section{Uji Organoleptik}

Rasa

Hasil uji organoleptik terhadap skor rasa minuman laktat dari bengkuang diperoleh antara 2,44 (tidak suka) dari 
perlakuan konsentrasi starter $10 \%$ dan lama fermentasi 20 jam hingga 3,00 (agak suka) dari perlakuan konsentrasi $10 \%$ dan lama fermentasi 22 jam. Nilai rata-rata tertinggi 3,00 (agak suka) diperoleh dari perlakuan konsentrasi starter $10 \%$ dan lama fermentasi 22 jam. Hal ini diduga karena pada penambahan starter $10 \%$ dan waktu fermentasi 22 jam, maka proses fermentasi yang berlangsung akan membentuk asam laktat yang berasal dari konversi karbohidrat dalam jumlah yang proporsional. Adanya asam laktat dan $\mathrm{pH}$ yang rendah pada produk menyebabkan timbulnya rasa khas minuman laktat dan sari buah yang terfermentasi oleh bakteri asam laktat, sehingga rasanya masih dapat diterima oleh panelis. Menurut Suryono, et al.,(2005), semakin tinggi jumlah asam laktat dalam lingkungan, maka potensi menurunnya $\mathrm{pH}$ lingkungan juga semakin besar, bahkan dapat memberi rasa yang spesifik pada produk. Selain itu, rasa dari minuman probiotik dari bengkuang ini juga dipengaruhi olah rasa manis yang berasal dari sukrosa yang ditambahkan pada saat akan dilakukan uji organoleptik.

\section{Aroma}

Dari hasil uji organoleptik skor ratarata aroma minuman laktat dari bengkuang pada penelitian ini berkisar antara 2,64-2,83 (agak suka). Skor rata-rata tertinggi yaitu 2,83(agak suka) diperoleh pada perlakuan penambahan konsentrasi starter $15 \%$ dan lama fermentasi 22 jam. Skor aroma tertinggi pada perlakuan penambahan konsentrasi starter $15 \%$ dan lama fermentasi 22 jam disebabkan karena pada perlakuan tersebut menghasilkan aroma khas minuman laktat yaitu aroma khas asam laktat. Hal ini diduga, pada penambahan konsentrasi starter $15 \%$ dan lama fermentasi 22 jam beberapa komponen nutrisi yang ada yang difermentasi oleh bakteri asam laktat menghasilkan komponen-komponen yang memberikan flavour khas minuman laktat seperti asam laktat, komponen karbonil, asetaldehid, aseton, diasetil dan zat-zat volatil lainnya (Tamamie dan deeth, 1980 dalam Setyaningsih, 1992). Selain itu, adanya aroma khas asam laktat juga dapat menutupi aroma yang ditimbulkan oleh bengkuang yaitu bau langu, sehingga aroma segar minuman laktat dapat lebih tercium.

\section{Warna}

Berdasarkan hasil uji organoleptik skor rata-rata warna minuman laktat dari bengkuang pada penelitian ini berkisar antara 2,94-3,00 (agak suka). Hasil uji organoleptik ini menunjukkan bahwa penerimaan panelis terhadap warna tidak begitu berbeda, dimana penerimaan panelis untuk semua sampel mempunyai skor yang sama yaitu agak suka. Penerimaan yang homogen untuk semua sampel disebabkan karena warna yang ada pada pada setiap sampel tidak ada perbedaan yang signifikan. Perubahan warna umunya disebabkan karena adanya proses pencoklatan baik enzimatis maupun non enzimatis pada bahab baku. Pada produk minuman laktat dari bengkuang, pencoklatan enzimatis tidak terjadi karena sifat bengkuang itu sendiri yang tidak mudah atau cepat mengalami proses pencoklatan seperti halnya buah-buah lain yaitu buah apel, pisang, dan lain sebagainya. Pencoklatan non enzimatis yang umumnya terjadi karena penggunaan suhu tinggi. Pada proses pemanasan suhu yang digunakan untuk pasteurisasi produk minuman laktat bengkuang hanyalah $80{ }^{\circ} \mathrm{C}$ sehingga proses pencoklatanpun tidak terjadi.

\section{Penerimaan Keseluruhan}

Dari hasil uji organoleptik menunjukkan bahwa skor rata-rata penerimaan keseluruhan minuman laktat dari bengkuang pada penelitian ini berkisar antara 2,73-3,07 (agak suka). Hasil uji organoleptik ini menunjukkan bahwa penerimaan panelis terhadap penerimaan keseluruhan minuman laktat dari bengkuang tidak begitu berbeda, dimana penerimaan panelis untuk semua sampel mempunyai skor yang sama yaitu agak suka. Penerimaan panelis secara keseluruhan untuk semua sampel minuman laktat menyatakan sama yaitu agak suka, diduga juga karena penerimaan terhadap beberapa parameter uji sebelumnya seperti warna dan aroma tidak ada perbedaan sehingga panelis beranggapan 
bahwa secara keseluruhan antarproduk tidak ada perbedaan.

\section{Penentuan Hasil Terbaik}

Berdasarkan hasil penelitian dapat diketahui bahwa penambahan konsentrasi starter dan lama fermentasi berpengaruh terhadap peningkatan total asam laktat, penurunan $\mathrm{pH}$, peningkatan total bakteri asam laktat, dan penerimaan terhadap rasa. Penentuan hasil terbaik didasarkan pada nilai total asam laktat yang mengacu pada SNI minuman laktat yaitu berkisar antara $0,5-2 \%$, nilai $\mathrm{pH}$ minuman laktat yaitu sekitar 3,8-4,6, total bakteri asam laktat > $10^{7}$ dan penerimaan tertinggi terhadap skor uji organoleptik.

Dari tabel diatas sampel dengan perlakuan konsentrasi starter 5\% dan lama fermentasi 18 jam memiliki karakteristik terbaik karena memiliki total asam laktat terendah. Berdasarkan hasil uji organoleptik, hanya skor rasa yang menunjukkan perbedaaan. Berdasarkan uraian tersebut maka dapat disimpulkan bahwa hasil terbaik diperoleh pada perlakuan konsentrasi starter 5\% dan lama fermentasi 18 jam dengan total asam laktat $1,74 \%, \mathrm{pH} 4,04$, total bakteri asam laktat 8,73 log koloni/ml, dan memiliki skor rasa 2,82 (agak suka).

\section{KESIMPULAN DAN SARAN}

\section{Kesimpulan}

Dari hasil penelitian dan pembahasan tersebut diatas dapat disimpulkan yaitu:

Konsentrasi starter 5\% dan lama fermentasi 18 jam menghasilkan minuman laktat bengkuang dengan karakteristik yang terbaik yaitu dengan total asam laktat $1,74 \%, \mathrm{pH} 4,04$, total bakteri asam laktat $8,73 \log$ koloni/ml, dan memiliki skor rasa 2,82 (agak suka).

\section{Saran}

1. Perlu untuk dilakukan penelitian lanjutan tentang penambahan bahan penstabil setelah fermentasi sehingga diperoleh produk yang lebih stabil.

2. Perlu untuk dilakukan penelitian tentang masa simpan dan kajian ekonomis minuman laktat dari bengkuang.

\section{UCAPAN TERIMA KASIH}

Ucapan terima kasih dan penghargaan setinggi-tingginya disampaikan kepada Rismanto, Alumni Jurusan Teknologi Hasil Pertanian, Fakultas Pertanian Universitas Lampung atas kerjasama, pengorbanan, dan jerih payah yang telah diberikan dalam melaksanakan penelitian ini.

\section{DAFTAR PUSTAKA}

Afrizal, M. 1989. Study Tingkat Penambahan Starter dan Lama Inkubasi terhadap Mutu Yoghurt. Tesis Teknologi Hasil Pertanian. Fakultas Pertanian. Universitas Lampung. Bandar Lampung.

Anonim. 2007a. Tanaman Obat. http://www. foodsci. uoguelph. ca/daityedu/ Tanaman Obat. html. Diakses tanggal 18 oktober 2008 .

Anonim. 2008a. Bengkuang. http://id.wikipedia.org/wiki/Bengkua ng. Diakses tanggal 18 Oktober 2008.

AOAC. 1990. Official Method of Analysis of AOAC. 14 ${ }^{\text {th }}$ Edition.AOAC Inc., Arlington, Virginia.

Evanikastri, 1997. Uji Aktivitas Antibakteri Patogen dan Pengadaan Skala pada Minuman Asam Laktat Bervitamin B12 dari Sari Wortel. Skripsi Fateta. IPB. Bogor.

Fardiaz, S. 1987. Penuntun Praktikum Mikrobiologi Pangan. Jurusan Teknologi Pangan dan Gizi. IPB. Bogor.

Helferich, W. and D. Westhoff. 1980. All About Yoghuert Prentice-hall Inc., Englewood Cliffs. New Jersey. 102 pp.

Kustianingrum, W. 2003. Pengaruh Jenis Starter dan Lama Fermentasi terhadap Sifat Kimia dan Organoleptik Minuman Fermentasi Laktat kecipir. Skripsi FP. Unila. Bandar Lampung.

Marniza. 2006. Kajian Pembuatan Minuman Kesehatan dari Sari Buah yang 
Difermentasi dengan Lactobacillus casei. Fakultas Pertanian. Unila.

Nining, S. 1982. Mempelajari pembuatan Yoghurt Susu Kambing. Tesis Sarjana. Fateta. IPB. Bogor.

Rahman, A. 1989. Pengantar Teknologo Fermentasi. PAU Pangan dan Gizi IPB. Bogor. 146 hal.

Safitri, M. 2005. Pengaruh Penambahan Glukosa dan Skim terhadap Karakteristik Sari Buah Sirsak yang Difermentasi oleh Lactobacillus casei. Skripsi. Fakultas Pertanian. Universitas Lampung. Bandar Lampung.

Setyaningsih, L. 1992. Pengaruh Jenis Kultur dan Penambahan Susu Skim Terhadap Mutu Yakult Kedelai. Skripsi Fakultas Teknologi Pertanian. IPB. Bogor.

Sihaloho, Jayanti Eni. 2008. Pengaruh komponen pembentuk gel (KPG) cincau hijau dan lama fermentasi terhadap sifat kimia dan mikrobiologi yoghurt sinbiotik. Skripsi. Fakultas Pertanian. THP. Universitas Lampung.

Sriwidowati. 2003. Efektivitas Bakteri Asam Laktat Pada Pembuatan Produk Fermentasi Berbahan Baku Nabati. http://www.unri.ac.id/jurnal/ jurnal natur/ vol5(2)/ Sri. pdf. Tanggal Akses 18 Oktober 2008.

Suryono, et al.,. 2005. Studi Pengaruh Penggunaan Bifidobakteria terhadap Flavor Yoghurt. Jurnal Teknologi dan Industri Pangan Vol. 16 - No. 1. IPB. Bogor.

Yamaguchi, M dan V.E. Rubatzky. 1998. Sayuran Dunia 1. ITB. Bandung. 313 hal.

Widowati, S dan Misgiyarta. 2003. Efektivitas Bakteri Asam Laktat Dalam Pembuatan Produk Fermentasi Berbasis Protein atau Susu Nabati. Prosiding Seminar Hasil Pertanian Rintisan dan Bioteknologi Tanaman. Hal 360-372.

Williams, C.N., J.O. Uzo. dan W.T.H. Peregrine. 1993. Produksi Sayuran di Daerah Tropika. UGM Press. Yogyakarta. 374 hal. 